\title{
Burnout in Science Teachers
}

\author{
Rajeev Deswal ${ }^{1}$, Savita ${ }^{2}$
}

\section{ABSTRACT}

The burnout is seen in almost all the profession such as nursing, teaching etc. This paper focuses on the burnout of science teachers in Haryana. And determine the likely factors that are associated with this phenomenon. It explored the different causal factors for burnout to study the problems in Indian context. All the teachers mentioned apathy is the major cause of teacher burnout. The student apathy produces stress on the teacher and develops burnout symptoms. The other area involving teacher burnout was that of administration, lack of respect, changes in student behavior were also contributing teacher burnout. Other factors causing burnout are Nepotism/Politics, paper work, overcrowded classes, and workload, Athletics over Academics, Serious nature and lack of resources or infrastructure. Thus overload of stress directly leads to teacher burnout.

Keywords: Burnout, Science Teachers

Teacher is the key figure in the education system. A teacher is anticipated to perform the role of analyst, facilitator, social worker and even parent of the beginner to some extent i.e. a unique personality. He influences the beginner by what he says and even more by what he does. His attitude towards pupils, his work and life in general, his philosophy of education, his interests, ideals influence learning are important for their growth (Yadav and Katyaynii 2013).

The Education Commission 1964-66 has expressed "The destiny of India is now being shaped in classroom. This we believe is no more rhetoric. The science and technology based education determines the level of prosperity, security and welfare of the people”. The role of teachers in the quality of education is most significant. Teacher is the ultimate agent who dispenses knowledge, evaluate learning outcomes and help pupils to overcome their difficulties and personal problems. The competence of teacher is of paramount importance in today's world and their responsibilities have also increased tremendously. On one hand, they have to keep themselves abreast with the latest advancements in their field and on the other hand they have to involve themselves in many co-curricular and administrative activities also. Thus for effective education, a teacher needs to do proper planning, manage classroom, be expert in the subject and also have expertise in

${ }^{1}$ D.I.E.T., Machhrauli, Jhajjar, Haryana

${ }^{2}$ Department of Botany, M.D. University, Rohtak

(C) 2015 I R Deswal, Savita; licensee IJIP. This is an Open Access Research distributed under the terms of the Creative Commons Attribution License (http://creativecommons.org/licenses/by/2.0), which permits unrestricted use, distribution, and reproduction in any Medium, provided the original work is properly cited. 


\section{Burnout in Science Teachers}

interpersonal relations. There is no doubt that a teacher in the quest to prove oneself in all these areas, over experts himself or herself and is likely to suffer from stress.

Various stressors of the teaching profession have been identified such as multiple roles and inability to reconcile different roles, strict standards of accountability, excessive workload, lack of authority and decision making powers, frequent transfers and financial constraints etc. Discipline problems among students especially students apathy, lack of co-operation, disrespect and overcrowded classrooms also acts as significant stressors in the teaching profession (Ever et al 2005). Whenever stress continues for long period, one may feel over crush and unable to deal effectively. In the long run, a sense of tiredness, frustration, hopelessness can creep in, which are perceived as symptoms of burnout. Burnout is an occupational hazard to which all members of helping professions are exposed, including teachers. Carter (1994) defines teacher burnout as physical, emotional and attitudinal exhaustion that begins with a feeling of uneasiness and mounts as the joy of teaching begins to gradually slip away. Although the symptoms of burnout may be very personal, they are generally "lack of" symptoms. The list includes lack of energy, joy, enthusiasm , satisfaction , motivation, interest, zest, dreams for life, ideas, concentration, self confidence, or humor (Me Gee-Cooper, 1990).

\section{Historical description of Burnout}

The term Burnout was first used by Graham Greene’s Novel in 1960 in which an architect quits his job . In 1974 Fraudbenger wrote a book with the title "Burnout : The high cost of high achievement” which provide the direct account of emotional depletion, loss of motivation and commitment and labeled it with term 'Burnout'.

In 1976, Maslach a social psychologist interviewed a wide range of human services workers about the emotional stress of their jobs and her book 'Burnout: The cost of caring describes burnout with precision. Thus, the two are credited for pioneer studies on burnout. The researches had clinical and social psychological perspectives. The clinical sides focused on symptoms of burnout and issues of mental health where as social perspective by Maslach had focus on relationship between provider and recipient, in the context of service occupations. The initial researches were descriptive, non empirical and qualitative in nature using techniques like interviews, case studies and on site observations.

The second phase of burnout research in 1980's was systematic and quantitative in nature with questionnaire surveys methodology. In the 1990's the empirical phase continued but the concept extended to other occupations beyond human services. The complex relationships among organizational factors and components of burnout were established and Burnout models were developed.

\section{Definition of Teacher Burnout}

Burnout was first defined by Freudeberger (1974) and involves feelings of failure and exhaustion resulting from excessive demands on a person's energy with insufficient reward for the effort. 


\section{Burnout in Science Teachers}

Other researchers have defined burnout as physiological distancing from work. Maslach (1976), Block (1978) and Freudenberger (1983) have identified many of the symptoms associated with burnout, which can be categorized into there groups: physical (e.g., exhaustion, lingering cold, frequent headaches, gastrointestinal disturbances, weight loss, sleeplessness and shortness of breath), psychological (e.g., changeable mood, irritability, depression, loss of caring for people, cynical attitude, increased frustration, feelings of helplessness, greater professional risk-taking (i.e., smoking, escapist drinking, drug use), and behavioral (e.g., deterioration in work performance and absenteeism). It is unlikely that any single isolated symptom can be viewed as an indication of burnout. Various combinations of the above and perhaps others represent the manifestations of burnout. If these issues are not addressed, eventually, the individual loses desire and motivation, and is unable to fight or flee what is perceived to be an impossible situation. On a more global scale, burnout can lead to serious consequences in the individual, the school and students.

Teaching can be considered a high-stress occupation. The education system has all the elements associated with stress: a bureaucratic structure, continuous evaluation of its processes and outcomes, and increasingly intensive interpersonal interactions with students, parents, colleagues, principals and the community. In addition, increased students misconduct, student apathy, overcrowded classrooms, inadequate salaries, demanding or unsupportive parents, budgetary constraints, expanding administrative loads, lack of infrastructural support, and an increasingly negative public opinion have contributed to an embattled and embittered teacher force in America and throughout the world.

Burnout tends to be contagious. When dissatisfied and depressed teachers are present in a school, others can very easily become lethargic, cynical, and discontented and, before long, the entire organization becomes a dispirited and uninviting place. According to Van der Sijde (1988), the school climate influences both the student and the teacher. He reported a positive relationship between teacher's work conditions and the amount of support they gave to students. In addition, he noted, that teachers' behavior depended on their perceptions of how their school functioned. Thus, teachers play an important role in establishing the overall tone of a school. According to Purkey (1970), teachers need to feel successful and good about themselves and their abilities before they can empower their students to feel the same. If, however, teachers are experiencing feelings of failure and/or lacking in personal satisfaction, their relationship with students and the overall school will ultimately suffer.

\section{OBJECTIVE}

The objective of this research is to investigate how many of science teachers participated in promotion of Science programme under TTS-MS suffered from teacher burnout. This investigation also attempted to discover the major factors contributing teacher burnout and the steps for prevention. My personal teaching experience indicated that student apathy would contribute mostly in the teacher burnout. 


\section{METHODS}

This research consisted 12 Science Teachers (with nine males and three females) from different schools teaching in district Jhajjar rural areas which participate in Science promotion programme. The group consisted of teachers who exhibited symptoms of teacher burnout and teachers who demonstrated characteristics opposite to those of teacher burnout. The facts were interviewed informally on the subject of teacher burnout. The information obtained from these interviews was used as a framework in the development of the teacher burnout survey.

These teachers were posed with the topic of teacher burnout and asked to elaborate on the subject. They were prompted to reflect on what they thought were the major contributors to burnout in their particular school and schools in general. The data (Table-1) presents a list of the topics discovered in the interviews and the percentage of teachers citing each topic as a potential cause of teacher burnout.

The teacher burnout survey was designed for the teachers to rate the contribution of 17 various factors for the burnout. A rating scale of one to five was given to each factor. The teachers were asked to judge the factors with this approach: 5- Major contributor; 4-Contributes considerably; 3- Contributes Somewhat; 2- Contributes rarely; 1- Does not contribute. General demographic information was also requested in the survey. Teachers were asked to indicate years of teaching experience, gender, extracurricular activities sponsored, subjects taught along with a question inquiring if the teacher felt burnout and also with additional thoughts or comments.

The interview method was to determine the percentage of teachers who indicated that they have suffered from teacher burnout (Table-2). An average of the rating for each contributing factor was then calculated in the three categories: entire group, teachers indicating 'yes' to having suffered from burnout and the teachers indicating 'no' to having suffered from burnout (Table3). This was used to determine which factor was considered the most influential in teacher burnout.

\section{Teacher Burnout Data}

Table 1: Topics of Burnout and Percentages

\begin{tabular}{|l|c|c|}
\hline \multicolumn{1}{|c|}{ Teacher Burnout Issue } & $\begin{array}{c}\text { Number Citing } \\
\text { Issue }\end{array}$ & $\begin{array}{c}\text { Percentage } \\
\text { Citing Issue }\end{array}$ \\
\hline Apathy (student/Parent/Faculty) & 12 & $100 \%$ \\
\hline Administration/Leadership & 10 & $83 \%$ \\
\hline Nepotism/Politics & 7 & $58 \%$ \\
\hline Student Behavior & 7 & $58 \%$ \\
\hline Lack of Respect & 8 & $67 \%$ \\
\hline Paperwork & 6 & $50 \%$ \\
\hline Legal Ramifications & 3 & $25 \%$ \\
\hline
\end{tabular}




\begin{tabular}{|l|l|l|}
\hline Technology Integration & 4 & $33 \%$ \\
\hline Lack of Variety & 2 & $50 \%$ \\
\hline Serious Nature & 3 & $25 \%$ \\
\hline Lack of Quality Prof. Dev. & 2 & $50 \%$ \\
\hline Athletics over Academics & 4 & $33 \%$ \\
\hline
\end{tabular}

Table 2. Number of Teachers with and without Burnout

\begin{tabular}{|c|c|c|c|c|}
\hline Total Teachers & \multicolumn{2}{|c|}{$\begin{array}{c}\text { Burnout Teachers with } \\
\text { percentage }\end{array}$} & \multicolumn{2}{|c|}{$\begin{array}{c}\text { No Burnout Teachers with } \\
\text { percentage }\end{array}$} \\
\hline 12 & 7 & $58 \%$ & 5 & $42 \%$ \\
\hline
\end{tabular}

Table-3: Burnout Category Rankings

\begin{tabular}{|l|c|c|c|}
\hline Category & $\begin{array}{c}\text { Average } \\
\text { Response } \\
\text { (All Teachers) }\end{array}$ & $\begin{array}{c}\text { Average } \\
\text { Response } \\
\text { (Burnout) }\end{array}$ & $\begin{array}{c}\text { Average } \\
\text { Response } \\
\text { (No Burnout) }\end{array}$ \\
\hline Increased Paperwork/ Documentation & 4.2 & 4.6 & 3.5 \\
\hline Student and/or Parent Apathy & 4.4 & 5.0 & 3.4 \\
\hline Work Overload & 4.0 & 4.0 & 3.5 \\
\hline Student Behavior/Lack of Respect & 4.0 & 4.2 & 3.3 \\
\hline A Particular Class & 3.4 & 4.0 & 2.9 \\
\hline Underpaid for Responsibilities & 3.6 & 3.7 & 3.4 \\
\hline Nepotism/Favoritism/Politics & 3.6 & 3.6 & 2.9 \\
\hline Administration & 3.1 & 3.5 & 2.8 \\
\hline Lack of Emphasis on Academics & 3.3 & 3.6 & 2.4 \\
\hline Powerlessness/Lack of Control & 3.3 & 3.4 & 3.0 \\
\hline Legal Ramifications & 3.0 & 3.1 & 3.3 \\
\hline Lack of Info/Support/Prof Dev. & 3.0 & 3.3 & 2.8 \\
\hline Poor Team Work/Isolation & 3.0 & 3.1 & 2.6 \\
\hline Lack of Variety & 3.0 & 2.9 & 2.4 \\
\hline Teacher Evaluations & 2.4 & 2.5 & 2.3 \\
\hline Technology & 2.2 & 2.4 & 2.3 \\
\hline Home/Personal Life & 2.0 & 2.2 & 2.0 \\
\hline Average of All Responses & 3.3 & 3.5 & 2.9 \\
\hline
\end{tabular}

\section{RESULT/INTERPRETATIONS}

The prevailing word in the data collection form the initial interviews was apathy. All the teachers mentioned apathy is the major cause of teacher burnout. The student apathy produces 
stress on the teacher and develops burnout symptoms. The other area involving teacher burnout was that of administration. Ten of the twelve teachers mentioned administrations/leadership as contributing to burnout. Similarly eight teachers mentioned lack of respect as well as changes in student behavior were also two characteristics contributing teacher burnout. Eight teachers discussed that the overall lack of respect from students is a major issue in the burnout. I feel that these areas cited in the interviews are closely related to student apathy. Respect is a form of responsibility. Those students who do not demonstrate this to their teachers or pears prove that they do not care. This type of apathy can carry over into the classroom and hinder the learning experience.

Similarly other factors causing burnout are Nepotism/Politics, paper work, over crowded classes, workload, Athletics over Academics, Serious nature and lack of resources or infrastructure. The comparison of education with the corporate world also discouraging teachers. Thus overload of stress directly leads to teacher burnout (Cedoline, 1982).

\section{Prevention of burnout:}

It is better that the roots of burnout are identified and eliminated before syndrome develops. Some steps for avoiding burnout are as:-

Step 1:- $\quad$ Have fun daily with your students.

Step 2:- $\quad$ Take care of your health.

Step 3:- $\quad$ Learn something new and share it with your students.

Step 4:- $\quad$ Help another teachers.

Step 5:- $\quad$ Make someone's day.

Step 6:- $\quad$ Lighten up.

Step 7:- $\quad$ Be a scientist.

Step 8:- $\quad$ Look for the positive.

Step 9:- $\quad$ Redecorate.

Step 10:- $\quad$ Trust students more.

\section{IMPLICATIONS/CONCLUSION}

This action research began as an analysis of teacher burnout in a science group from different schools and developed into the identification of my personal burnout. I now have a term to describe the felling of the lost interest and motivation that I experienced. I have come to the realization that burnout can effect any teacher regardless of experience, gender or subject. I have also realized that my own perfectionism, which is often associated with excellence, contributes much stress to my life and leads to burnout. My desire for students also to seek high levels of the achievements has resulted in the distress for me because of their rampant apathy. In the schools, student apathy is a major problem, which has been documented throughout this research project. This problem has increased the burnout levels of the majority of the teachers in the schools and has even caused some teachers to turn away from the classroom altogether. Park (2002) 


\section{Burnout in Science Teachers}

describes this phenomenon as ironic. She states that the best teachers are the most susceptible to burnout. Their unrelenting dedication to students can lead them to take on too many tasks, which ends up draining their creative energy. She states that this is especially true when the students are apathetic towards the efforts of their teachers.

There are many possibilities for other action projects stemming from the topic of teacher burnout. The most obvious one would be on the best methods of Prevention and/or strategies for curing teacher burnout. Another would be to analyze the elementary school level to see if student apathy was a major contributor to burnout in that area. This research could be conducted in a similar manner, or it could be framed to just probe into what the major contributions to teacher burnout among school science teachers. We have actually presented this survey to the science teachers and plan to analyze the data in effort to identify possible signs of burnout. Other potential studies previously mentioned involve the relationship of extracurricular sponsorships to teacher burnout and the pressures of non-tenured or less experienced teachers and teacher burnout.

The remaining implication of this study is that teachers need help in dealing with burnout. They also need support to rectify the stigma that is student apathy. Society need to understand the pressures and challenges that surround educators. It also need replace the unrealistic expectations it places upon teacher with encouragement and a helping hand. Palmer (1999) refers to this by stating, "Teaching and learning are critical to our individual and collective survival and to the quality of our lives. The pace of change has us snarled in complexities, confusions, and conflicts. Panic- stricken by the demands of our day, people need scapegoats for the problems they can not solve, and the teachers make an easy target. We blame them for being unable to cure social ills that no one knows how to treats; we insist that they instantly adopt whatever " solution" has most recently been concocted by our national panacea machine; and in the process we sometimes demoralize the very teachers who could help us find our way."

\section{REFERENCES}

Block, A.J. (1978). Combat neurosis in inner city school. American journal of psychiatry, 135, 1189-1192.

Carter, S. (1994). Interventions: Organizing systems to support competent social behavior in children and youth. Eugene, OR: Western Regional Resource Center. (ERIC Document Reproduction Service No. ED 380 971)

Cedoline, A.J. (1982). Job bournout in public education:symptoms, causes and survival skills. NY: Teachers College Press.

Ever, W., tomic, W. and Brouwers, A. (2005). does equity sensitivity moderate the relationship between self efficiency beliefs and the teacher were not representative research in social psychology, 25,35-46

Fraudenberger, H.J. (1974). Staff burnout journal of social 30, 159-165. 


\section{Burnout in Science Teachers}

Freudenberger, H.J. (1983). burnout: contemporary issues, trends and concern. In B.A. farber (Ed.). stress and burnout in human services professions (76-145) new York: Pergamum Press.

Kothari, D.S. (1966). Chairman. Report of education commission 1964-1966 Govt. of India, New Delhi

Maslach, C. (1976). Burnout. Human Behaviour.5:16-22.

McGee-Cooper, A. (1990). You don't have to go home from work exhausted! Dallas: Bowen and Rogers.

Park, A. (2002). Battling teacher burnout. Focal points,20.

Plamer, P. (1999). The courage to teach. San Francisco, CA: Jossey-Bass Publishers.

Purkey, W.W. (1970). Self concept and school achievement. Englewood Cliffs, NJ:Prentice Hall.

Vander Sijde, P.C. (1988). Relationships of classroom climate with student learning outcomes and school climate. Journal of classroom interaction. 23:40-47.

Yadav, P.N.S., Katyaynii, A. (2013). burnout in teachers- A serious quality concern in the education process. New frontier in education. 47-52 